\title{
Response of Growth, Productivity and Quality of Some Egyptian Wheat Cultivars to Different Irrigation Regimes
}

\author{
M.F. Seleiman and M.S.M. Abdel-Aal ${ }^{\#}$ \\ Department of Crop Science, Faculty of Agriculture, Menoufia University, Shebin El \\ koom, Egypt.
}

\begin{abstract}
T WO field experiments were done at the Experimental Farm, Faculty of Agriculture, Menoufia University, Shebin El koom, Egypt, during 2015/2016 and 2016/2017 seasons, to study the response of growth, productivity and quality of four wheat cultivars (cvs.), i.e. Gemmeiza 12, Misr 3, Sakha 95 and Shandaweel 1 to three irrigation regimes, i.e. I (five irrigations at tillering, stem elongation, booting, heading and ripening stages), as a control, $\mathrm{I}_{2}$ (four irrigations with skipping one irrigation at ripening stage) and $I_{3}$ (three irrigations with skipping two irrigations at each of heading and ripening stages). The results showed that exposing wheat plants to drought stress by skipping two irrigations ( $\mathrm{I}_{3}$ regime) significantly decreased growth characters (plant height, flag leaf area, total chlorophyll and days from sowing to heading as well as maturity), grain yield components (no. of spikes $/ \mathrm{m}^{2}$, spike length, no. of spikelets/spike, no. of grains/spikelet, no. of grains/spike, 1000 grain weight and grain weight/ spike), yields/fad (grain, straw and biological), translocation indices (crop and harvest indices) and grain yielding ability as well as grain quality (protein and carbohydrate yields/fad and carbohydrate percentage) compared to full irrigation treatment ( $\mathrm{I}_{1}$ regime). Reversely, protein percentage was significantly increased when the plants were exposed to skipping two irrigations at heading and ripening stages $\left(\mathrm{I}_{3}\right.$ regime). However, there are no significant differences between full irrigation ( $\mathrm{I}_{1}$ regime) and skipping one irrigation only at ripening stage $\left(\mathrm{I}_{2}\right.$ regime) for grain, straw, biological yields/fad and most related traits. Sakha 95 and Gemmeiza $1_{2}$ cultivars were superior to the other cultivars in most traits over all tested irrigation regimes. However, Misr 3 and Shandaweel 1 cultivars had values of drought susceptibility index (DSI) less than one either at moderate $\left(\mathrm{I}_{2}\right.$ regime) or at severe drought stress $\left(\mathrm{I}_{3}\right.$ regime), indicating that such cultivars were relatively tolerant to drought stress compared to the other tested cultivars. The interaction between the two tested factors showed that the application of four irrigations ( $\mathrm{I}_{2}$ regime) to wheat cultivars namely Misr 3 and Shandaweel 1 are useful to save water consumption without significant reduction in wheat productivity.
\end{abstract}

Keywords: Wheat, Irrigation regimes, Cultivars, Drought, Productivity.

\section{Inroduction}

The world faces one of the most critical challenges which it is the need to cover the food necessities of the melodramatically growing population. In last few years, wheat (Triticum aestivum $\mathrm{L}$.) production did not met requirements of consumers and as a result of this the hunger and prices were increased worldwide. The need for wheat production is predictable to increase in 2050 by $60.0 \%$ based on the expected population, i.e. 9 billion of the world (Lucas, 2013). Wheat is considered one of the most vital cereal crops not only in Egypt, but also in the whole world, as it is used for food and fodder. It provides around
$21.0 \%$ of protein and $19.0 \%$ of the calories that are needed for daily human demand at the universal scale (Braun et al., 2010). Worldwide, roughly $732.0 \mathrm{Mt}$ of wheat grains was produced from $218.5 \mathrm{M}$ ha with an average of 3.3ton grains ha $^{-1}$ during 2013 (FAOSTAT, 2014). In Egypt, the production of wheat was about $9.0 \mathrm{Mt}$ obtained from about $3.3 \mathrm{M}$ fad $\left(\right.$ faddan $\left.=4200 \mathrm{~m}^{2}\right)$, however, there is a big gap between the Egyptian production (9.0Mt) of wheat and the Egyptian consumption (19.0Mt) of this crop (FAOSTAT, 2015). Recently, a great attention has been directed paid to increase the productivity of such important crop, therefore the strategies of agricultural policies have to be focused on minimizing the gap between

\#Corresponding author emails: moha3b3al@gmail.com DOI: 10.21608 /agro.2018.6352.1136

(C)2018 National Information and Documentation Center (NIDOC) 
the Egyptian production and consumption via increasing wheat production through using tolerant genotypes for biotic and abiotic stress circumstances and using the optimal agricultural practices taking into account the limited available water reserves on global scale (Loggini et al., 1999 and Varga et al., 2015). One of the major effects of climate changes particularly in arid and semi-arid regions will be increased frequency and severity of drought stress which is considered the most critical environmental stresses and one of the limiting factors in the wheat-producing regions (IPCC, 2013 and AlGhzawi et al., 2018). Water stress can result in a negative impact on phenological growth stages, reduced biomass production and grain yield (Kilic \& Yagabsanlar, 2010 and Seleiman et al., 2011). The plant response for water stress conditions depends on different factors for instance growth stage, severity of water stress, long of stress period and cultivars (Beltrano \& Marta, 2008). Generally, drought resistance mechanisms can be defined by plant breeders through selecting the highest grain yield and its stability under water stress conditions (Fischer \& Maurer, 1978, Seleiman et al., 2011 and El Hag, 2017). The ability of wheat cultivars to produce high grain yield under different conditions of stress and non-stress environments is very imperative (Rashid et al., 2003). In addition, the improvement of wheat cultivars yield under water stress can be due to the extended grain filling period, high chlorophyll content, better sustained turgor, or all of them as a combination
(Paknejad et al., 2007).

Therefore, the objective of the current research was to investigate the effect of different irrigation regimes on growth, productivity and quality of four bread wheat cultivars.

\section{Materials and Methods}

Two field experiments were conducted during two growing seasons 2015/2016 and 2016/2017 at Experimental Farm, Faculty of Agriculture, Menoufia University, Shebin El-koom, Egypt (Latitude: $30^{\circ} 33^{\prime} 31^{\prime \prime}$ and Longitude: $31^{\circ} 00^{\prime}$ 36 ) to investigate the effect of three water regimes $\left(\mathrm{I}_{1}=\right.$ Five irrigations as control, $\mathrm{I}_{2}=$ Four irrigations and $\mathrm{I}_{3}=$ Three irrigations) on the growth, yield and quality of four Egyptian bread wheat cultivars, i.e. three new cultivars (Gemmeiza 12, Misr 3 and Sakha 95) as well as Shandaweel 1 (drought tolerant cultivar). Five irrigations $\left(\mathrm{I}_{1}\right)$ was applied at tillering, stem elongation, booting, heading and ripening stages, while four irrigations $\left(\mathrm{I}_{2}\right)$ was applied at all last stages except at ripening stage. Moreover, three irrigations $\left(\mathrm{I}_{3}\right)$ was applied only at tillering, stem elongation and booting stages. All irrigation scheduling at different wheat growth stages are shown in Table 1.

The grains of the four tested wheat cultivars were obtained from Agriculture Research Centre, Ministry of Agriculture, Egypt. The pedigree of the tested four cultivars are presented in Table 2.

TABLE 1. Irrigation scheduling at different wheat growth stages.

\begin{tabular}{lccccc}
\hline \multirow{2}{*}{ Irrigation regimes } & \multicolumn{3}{c}{ Wheat growth stages } \\
\cline { 2 - 5 } & Tillering & Stem elongation & Booting & Heading & Ripening \\
\hline $\mathrm{I}_{1}$ & $\sqrt{ }$ & $\sqrt{ }$ & $\sqrt{ }$ & $\sqrt{ }$ & $\sqrt{ }$ \\
$\mathrm{I}_{2}$ & $\sqrt{ }$ & $\sqrt{ }$ & $\sqrt{ }$ & $\times$ \\
$\mathrm{I}_{3}$ & $\sqrt{ }$ & & & $\times$ & $\times$ \\
\hline
\end{tabular}

$-\sqrt{ }=$ Irrigation; $x=$ No irrigation.

$-\mathrm{I}_{1}=$ Control (five irrigations), $\mathrm{I}_{2}=$ Four irrigations and $\mathrm{I}_{3}=$ Three irrigations.

TABLE 2. Name and pedigree of the tested four bread wheat cultivars.

\begin{tabular}{ll}
\hline Cultivar name & \multicolumn{1}{c}{ Pedigree } \\
\hline Gemmeiza 12 & OTUS/3/SARA/THB//VEE/CMSS97YOO227S-5Y-010M-010Y-010M-2Y-1M-0Y-OGM \\
Misr 3 & PAS TOR//S ITE/MO/3/CHEN/AEGILOPS SQUARROS A(TAUS)/BCN/4/W BLL 1/ \\
& CMSA01Y00158S-040P0Y-040M-030ZTM-040SY-26M-0Y-0SY-0S \\
Sakha 95 & ATTILA*2/PBW65*2/KACHU/CMSS06Y00582T-099TOPM-099Y-099ZTM-099Y-099M- \\
& $\begin{array}{l}\text { 10WGY-0B-0EGY } \\
\text { Shandaweel 1 }\end{array}$ \\
& $\begin{array}{l}\text { Site/Mo/4/Nac/Th. Ac//3* Pvn/3/Mirlo/Buc/CMSS93 B00S 67S-72Y-010M-010Y-010M-3Y-0M- } \\
\text { 0THY-0SH }\end{array}$ \\
\hline
\end{tabular}

Egypt. J. Agron. 40, No.3 (2018) 
The experimental design was a split plot with three replications. Water regime treatments were randomly placed in main plots, where wheat cultivars were randomly allocated in sub plots. The size of each experimental unit was $12 \mathrm{~m}^{2}$ ( $4 \mathrm{~m}$ length $\times 3 \mathrm{~m}$ width). All plots were sown on $14^{\text {th }}$ November 2015 and 2016, with a seeding rate of $60 \mathrm{~kg} \mathrm{fad}^{-1}$. The grains were manually drilled on rows at $10 \mathrm{~cm}$ apart in about $3 \mathrm{~cm}$ depth. Maize (Zea mays L.) was the previous summer crop in both seasons. Phosphorus fertilizer was applied at a rate of $15.0 \mathrm{~kg} \mathrm{P}_{2} \mathrm{O}_{5}$ fad $^{-1}$ as calcium superphosphate $\left(15.5 \% \mathrm{P}_{2} \mathrm{O}_{5}\right)$ prior of wheat sowing. Nitrogen fertilizer was applied at a rate of $75 \mathrm{~kg} \mathrm{fad}^{-1}($ Urea $46 \% \mathrm{~N}$ ) and it was splitted into two equal doses, i.e. before first and second irrigations. Weeds grown in wheat plots were controlled manually and chemically when it was needed. Soil samples prior sowing dates in both seasons were collected from $1-15 \mathrm{~cm}$ depth for mechanical and chemical analysis as described by Jackson (1973) and Chapman \& Pratt (1978). Mechanical and chemical analysis of soil are presented in Table 3. Weather data for the experimental site during the two growing seasons of 2015/2016 and 2016/2017 are presented in Table 4.

\section{Measurements}

Growth characters

At 100 days after sowing (DAS), ten wheat plants from each plot were randomly taken to record the following growth traits (plant height and flag leaf area). Flag leaf area $\left(\mathrm{cm}^{2}\right)$ was estimated according to the method described by Thomas (1975). Moreover, soil-plant analysis development. (SPAD measurements) were recorded from the middle of flag leaf of ten wheat plants in each plot using SPAD meter (SPAD502, Minolta, Japan). In additions, the following phenological development stages were recorded: Days from sowing to heading (from sowing till $50 \%$ of spikes emerge completely from the flag sheath) as well as days from sowing to maturity (days from sowing till $50 \%$ of peduncles turned yellow)

\section{Yield and its components}

At harvest, $12^{\text {th }}$ May 2016 and $18^{\text {th }}$ May 2017, ten wheat plants were randomly taken from each sub-plot for measuring number of spikes $\mathrm{m}^{-2}$, spike length $(\mathrm{cm})$, number of spikelets spike ${ }^{-1}$, number of grains spikelets ${ }^{-1}$, number of grains spike ${ }^{-1}$, 1000-grain weight $(\mathrm{g})$ and grains weight spike ${ }^{-1}$ (g). Also, grain, straw and biological yields per fad were calculated by harvesting plants of one $\mathrm{m}^{2}$ at ground level from each sub-plot. Translocation indices (crop and harvest indices) were calculated as follows:

$$
\begin{aligned}
& \text { Harvest index }=\left(\text { Grain yield }_{\text {fad }}{ }^{-1} \div \text { Biological yield fad }^{-1}\right) \times 100 \\
& \text { Crop index }=\left({\text { Grain yield } \text { fad }^{-1} \div \text { Straw yield fad }}^{-1} \times 100\right.
\end{aligned}
$$

Also, Grain yield ability $\left(\mathrm{kg}\right.$ day $\left.^{-1}\right)$ was calculated as follows:

Grain yield ability $\left(\mathrm{kg} \mathrm{day}^{-1}\right)=\frac{\text { Grain yield }\left(\mathrm{kg} \mathrm{fad}^{-1}\right)}{\text { Number of days from sowing to maturity }}$

Drought susceptibility index (DSI) was used to characterize the relative drought stress tolerance of various cultivars. It was calculated independently the mean yield of each cultivar under stress and without stress condition using the following formula described by Fischer \& Maurer (1978)

$$
\mathrm{DSI}=\frac{1-\mathrm{Y} / \mathrm{Yp}}{\mathrm{D}}
$$

where, $Y=$ Grain yield of a genotype under drought, $Y p=$ Grain yield of a genotype under without drought and $\mathrm{D}=$ Drought intensity= 1 -mean $\mathrm{X} / \mathrm{Xp}(\mathrm{X}=$ Mean grain yield of all genotypes under drought and $\mathrm{Xp}=$ Mean grain yield of all genotypes under without drought) (DSI $>1=$ The cultivar was tolerant, DSI $<1=$ The cultivar was susceptible).

\begin{tabular}{|c|c|c|c|c|c|c|c|c|c|c|}
\hline \multirow{3}{*}{ Seasons } & \multicolumn{4}{|c|}{ Mechanical properties } & \multicolumn{6}{|c|}{ Chemical properties } \\
\hline & \multirow{2}{*}{$\begin{array}{c}\text { Sand } \\
(\%)\end{array}$} & \multirow{2}{*}{ Silt (\%) } & \multirow{2}{*}{$\begin{array}{l}\text { Clay } \\
(\%)\end{array}$} & \multirow{2}{*}{ Soil texture } & \multirow{2}{*}{$\begin{array}{c}E C \\
\left(d_{S} ~ m^{-1}\right)\end{array}$} & \multirow{2}{*}{ pH } & \multirow{2}{*}{$\begin{array}{c}\text { Organic } \\
\text { matter }(\%)\end{array}$} & \multicolumn{3}{|c|}{ Available (ppm) } \\
\hline & & & & & & & & $\mathbf{N}$ & $\mathbf{P}$ & $\mathbf{K}$ \\
\hline $2015 / 2016$ & 21.84 & 40.60 & 37.56 & Clay loam & 0.81 & 7.1 & 1.87 & 27.46 & 10.13 & 294.18 \\
\hline $2016 / 2017$ & 21.05 & 41.52 & 37.43 & Clay loam & 0.77 & 7.2 & 1.79 & 28.95 & 9.05 & 326.91 \\
\hline
\end{tabular}

TABLE 3. Mechanical, chemical and physical properties of the experimental soil before the cultivation during 2015 / 2016 and 2016 / 2017 seasons 
TABLE 4. Average of air temperature, relative humidity and precipitation level during 2015/2016 and 2016/2017 seasons.

\begin{tabular}{lcccccc}
\hline & Parameters & \multicolumn{2}{c}{ Air Temperature $\left({ }^{\circ} \mathbf{C}\right)$} & \multicolumn{2}{c}{ Relative humidity (\%) } & \multicolumn{2}{c}{ Precipitation $(\mathbf{m m})$} \\
\cline { 2 - 7 } Months & Season 1 & Season 2 & Season 1 & Season 2 & Season 1 & Season 2 \\
\hline September & 28.76 & 26.67 & 46.19 & 48.68 & 2.10 & 0.00 \\
October & 24.09 & 23.50 & 56.49 & 56.85 & 13.30 & 4.90 \\
November & 19.18 & 18.82 & 63.34 & 57.02 & 15.70 & 10.70 \\
December & 14.27 & 12.75 & 67.53 & 61.46 & 29.80 & 24.80 \\
January & 11.68 & 10.92 & 61.25 & 61.22 & 19.10 & 6.90 \\
February & 15.28 & 12.41 & 53.89 & 60.56 & 31.20 & 15.50 \\
March & 17.28 & 16.27 & 46.10 & 51.50 & 7.20 & 9.60 \\
April & 22.39 & 19.85 & 38.61 & 43.50 & 7.50 & 5.00 \\
May & 24.65 & 24.72 & 38.60 & 39.09 & 1.10 & 2.10 \\
\hline
\end{tabular}

Source: Central Laboratory for Agricultural Climate, Agricultural Research Center, Ministry of Agriculture \& Land Reclamation, Egypt

Grain quality

Wheat grains $(\sim 20 \mathrm{~g})$ were milled into a fine powder using a UDY cyclone mill (Udy Corporation, Colorado, USA) and the powder was then passed through a $0.5 \mathrm{~mm}$ sieve. Finally, the powder was used in the analysis of total crude protein and carbohydrate content. Total nitrogen content was analyzed using micro-Kjeldahl method (Tecator, 1991) and then total crude protein $\%$ was calculated by multiplying total $\mathrm{N} \% \times 5.7$. Total carbohydrate in grinded wheat grains was analyzed as described in the method of Dubois et al. (1956).

\section{Statistical analysis}

Data of growth, yield and quality traits were subjected to analysis of variance (ANOVA) using PASW statistics 21.0 (IBM Inc., Chicago, IL, United States of America). Least Significant Difference (LSD at $\mathrm{P} \leq 0.05$ ) was used to compare the differences between mean of treatments. Simple correlation coefficient between grain yield, growth and some quality traits was determined using PASW program.

\section{$\underline{\text { Results and Discussion }}$}

Growth characters and phenological development stages

Table 5 indicated that studied growth traits (Plant height and flag leaf area) and photosynthetic pigments (total chlorophyll) at 100 days after sowing as well as phenological development stages (days from sowing to heading and days from sowing to maturity) of wheat plant were significantly affected by the tested irrigation regimes in 2015/2016 and 2016/2017 growing seasons. Application of five irrigations (control, $I_{1}$ ) at tillering, stem elongation, booting, heading and ripening stages significantly increased plant height, flag leaf area and total chlorophyll as well as days to heading and to maturity as compared with the other tested irrigation regimes, i.e. four irrigations $\left(\mathrm{I}_{2}\right)$ at tillering, stem elongation, booting and heading stages, as well as three irrigations $\left(\mathrm{I}_{3}\right)$ at tillering, stem elongation and booting stages which produced the medium and lowest values of abovementioned traits, respectively. These results are fairly true in the two seasons. The superiority of growth traits, total chlorophyll and phenological development stages obtained herein at full irrigation regime (five irrigations) may be due to that the sufficient soil moisture in the root zone help the plants to absorb greater amount of water and nutrients which enhancing internodes elongation and cell division as well as improving pigments and photosynthetic process and metabolites accumulation and consequently increased growth periods. In this concern, many researchers reported that providing the wheat plants with sufficient moisture caused an increase in plant height (Razaq et al., 2016, Soomro et al., 2016 and El Hag, 2017), flag leaf area (ElMetwally et al., 2015), chlorophyll (Abdelraouf et al., 2013 and Al-Ghzawi et al., 2018) and days from sowing till heading and maturity (Ibrahim et al., 2010 and Mekkei \& El Haggan, 2014).

The data in Table 5 show that there are significant differences among the four tested wheat cultivars in the studied growth characters, total chlorophyll and phenological development 
stages in both growing seasons. Generally, it can be noted that the highest significant values were obtained by cultivars of Misr 3 for plant height $(107.86 \mathrm{~cm})$, Gemmeiza $12 \mathrm{cv}$. for flag leaf area $\left(40.21 \mathrm{~cm}^{2}\right)$ and Sakha $95 \mathrm{cv}$. for total chlorophyll (47.16) as well as number of days from sowing to heading and days to maturity for Misr $3 \mathrm{cv}$. (97.28 and 137.89 days, respectively), as an average of the two seasons. However, Shandaweel $1 \mathrm{cv}$. had the lowest significant values of flag leaf area $\left(35.86 \mathrm{~cm}^{2}\right)$, total chlorophyll $(42.33)$ and days to maturity (135.12 days) as an average of both seasons. From these results, it can be noted that Shandaweel $1 \mathrm{cv}$. had shorter vegetative growth period and consequently it was matured earlier than the other tested cultivars. The early maturity of such cultivar may be caused a decrease in flag leaf area and total chlorophyll. In this concern, other investigators found variation among some wheat varieties in their plant height (Mekkei \& El Haggan, 2014; Abdelkhalek et al., 2015 and Awad et al., 2015), flag leaf area (Zaki et al., 2007), chlorophyll (Kilic \& Yagbasanlar, 2010 and Akter et al., 2018) and no. of days to heading and to maturity (Abd El-Rahman \& El-Saidy, 2016, El Hag, 2017 and El Hag \& Shahein, 2017).

The interaction between irrigation regimes and wheat cultivars was found to be significant for growth characters (plant height and flag leaf area) as well as days to maturity in both seasons, while, the interaction between both factors did not reach the $5 \%$ level of significance in the first and/ or second seasons for the rest studied characters as shown in Table 5. The data illustrated in Fig. 1 showed that the four wheat cultivars had various reaction to different irrigation regimes in terms of the abovementioned growth characters. The highest values of plant height (115.0 and $109.8 \mathrm{~cm}$ ) and number of days from sowing to maturity (145.0 and 144.3 days) belonged to Misr $3 \mathrm{cv}$., while, the maximum values of flag leaf area $\left(42.2\right.$ and $\left.43.5 \mathrm{~cm}^{2}\right)$ belonged to Gemmeiza $12 \mathrm{cv}$. under full irrigation regime $\left(\mathrm{I}_{1}\right)$ in the first and second seasons, respectively. On the other hand, the lowest values of plant height (91.0 and $92.8 \mathrm{~cm}$ ) were obtained by Sakha $95 \mathrm{cv}$., while that of flag leaf area $\left(31.1\right.$ and $\left.31.6 \mathrm{~cm}^{2}\right)$ and days to maturity (129.0 and 130.0 days) were recorded by Shandaweel $1 \mathrm{cv}$. when they exposed to drought stress at heading and ripening stages ( $\mathrm{I}_{3}$ regime) in the first and second seasons, respectively. In this respect, other investigators found that the interaction between drought stress and wheat cultivars had significant effect on plant height as reported by Abdelkhalek et al. (2015) and Awad et al. (2015) as well as days to maturity as recorded by Kilic \& Yagbasanlar (2010) and El Hag (2017).

\section{Yield components}

Table 6 showed that there were significant differences between the three irrigation regimes for yield components of wheat in both seasons. Exposing wheat plant to drought by skipping an irrigation at ripening stage (irrigation four times, $\mathrm{I}_{2}$ ), as well as at heading and ripening stages (irrigation three times, $\mathrm{I}_{3}$ ) caused significant reduction in each of no. of spikes $/ \mathrm{m}^{2}(0.87$ and $10.64 \%)$, spike length (9.90 and $15.37 \%)$, number of spikelets/spike (5.11 and 9.60\%), number of grains/spikelet (1.40 and $21.48 \%$ ), number of grains/spike (6.72 and 28.46\%), 1000 grain weight (4.74 and $11.39 \%)$ and grain weight/spike (12.12 and $18.82 \%$ ) lower than those irrigated 5 times (full irrigation, $\mathrm{I}_{1}$ ), respectively, as an average of both seasons. From these results, it can be noticed that the reduction in the abovementioned yield components was more pronounced when the plants were exposed to drought stress at heading and ripening stages $\left(\mathrm{I}_{3}\right.$ regime $)$ than those exposed to drought stress at ripening stage only ( $\mathrm{I}_{2}$ regime). The severe reduction in yield components obtained herein by skipping two irrigations $\left(\mathrm{I}_{3}\right.$ regime $)$ may be due to the obvious reduction in growth characters and phenological development stages as shown previously in Table 5 and consequently decreased the dry matter accumulation and fertility of florets which affect the number of spikes $/ \mathrm{m}^{2}$ as well as number and weight of grains per spike. In this respect, many investigators found a reduction in number of each of spikelets/spike and grains/spike as well as 1000 grain weight by omitting irrigation at stem elongation and anthesis stages (Akram, 2011) as well as flowering stage (Gameh et al., 2017). Moreover, Mekkei \& El Haggan (2014) found that skipping irrigation at grain formation stage caused a reduction in number of spikes $/ \mathrm{m}^{2}$ and grain weight/spike.

The data in Table 6 showed significant differences were observed in most studied yield components among the four tested wheat cultivars in both seasons. Gemmeiza $12 \mathrm{cv}$. had the highest significant values of number of spikes $/ \mathrm{m}^{2}$ (460.70 spikes), spike length $(11.98 \mathrm{~cm})$, number of spikelets/spike (22.26 spikelets), number of grains/spike (58.43 grains) and grain weight/spike 
(2.79gm). However, Shandaweel $1 \mathrm{cv}$. produced the lowest values, i.e. 385.80 spikes, $11.41 \mathrm{~cm}$, 20.25 spikelets, 53.37 grains and $2.33 \mathrm{gm}$ for the same irrespective abovementioned yield components, as an average of both seasons. The maximum and minimum values of 1000 grain weight were recorded by Gemmeiza 12 and Misr 3 cvs, respectively in both seasons. On the other hand, the differences among the four tested cultivars were not great enough to the reach the significance level at $5 \%$ for number of grains/ spikelets. The superiority of Gemmeiza $12 \mathrm{cv}$. in the yield component parameters may be due to the increase in its flag leaf area and total chlorophyll content Table 5 which led to a promotion in the photosynthesis activity and consequently produced the great amount of metabolites synthesized in such cultivar plants. The variation among some Egyptian bread cultivars were previously detected by other investigators for number of spikes $/ \mathrm{m}^{2}$ (Abdelkhalek et al., 2015 and EL Hag \& Shahein, 2017), spike length (Zaki et al., 2007 and Mekkei \& El Haggan, 2014) number of grains/spike and 1000 grain weight (Milad et al., 2016 and El Hag, 2017) as well as grain weight/spike (Seleiman et al., 2010 and Gameh et al., 2017).

The interaction effect between irrigation regimes and wheat cultivars was significantly differed for grain weight/spike and 1000 grain weight in both seasons Table 6. However, the rest studied traits of yield components were not significantly affected by the interaction between the two factors in the first and/or second seasons, therefore the data were excluded. The data illustrated in Fig. 2 show that the highest values of grain weight/spike (3.39 and 3.50gm) belonged to Gemmeiza $12 \mathrm{cv}$. while those of 1000 grain weight (45.69 and 46.03gm) belonged to Sakha $95 \mathrm{cv}$. when their plants were irrigated 5 times (full irrigation, $\mathrm{I}_{1}$ regime) in the first and second seasons, respectively. On the other hand, exposing wheat plants to severe drought stress $\left(\mathrm{I}_{3}\right.$ regime) produced the lowest values of grain weight/spike (2.15 and 2.33gm) in Shandaweel $1 \mathrm{cv}$. and those of 1000 grain weight (37.37 and 37.63gm) in Misr $3 \mathrm{cv}$. in the first and second seasons, respectively. The differences among the tested wheat cultivars under different irrigation regimes may be referred to their genetic constitutions and their interaction with prevailing environmental conditions such as drought stress. In this respect, many researchers found significant interaction between wheat genotypes and irrigation treatments for grain weight/spike (Kilic \& Yagabsanlar, 2010 and Gameh et al., 2017) and 1000 grain weight (Awad et al., 2015; Milad et al., 2016 and El Hag, 2017).

Yields, translocation indices and grain yielding ability

Table 7 showed that grain, straw and biological yields/fad were significantly decreased when the plants were exposed to drought stress at heading and ripening stages (application of 3 irrigations, $\mathrm{I}_{3}$ regime). This reduction amounted to 18.57 and $15.09 \%$ for grain yield, 13.53 and $12.86 \%$ for straw yield and 15.60 and $13.73 \%$ for biological yield compared to full irrigation regime (application of 5 irrigations, $\mathrm{I}_{1}$ regime) in the first and second seasons, respectively. However, there are no significant differences between exposing wheat plants to drought stress at heading stage only (application of 4 irrigations, $\mathrm{I}_{2}$ regime ) and full irrigation (application of 5 irrigations, $I_{1}$ regime ) for grain yield/fad in both seasons and for straw and biological yields/fad in the second season. From these results, it can be suggested that the moderate deficit of water stress at ripening stage only can reduce water consumption without significant reduction in wheat yields. These results are confirmed with that obtained by Ibrahim et al. (2010) who found that increasing the number of irrigation times from 5 to 6 did not significantly increased grain yield/ha. Moreover, it can be suggested that the reduction in wheat yields obtained herein under drought stress by skipping two irrigations (at heading and ripening stages) may be due to the severe depression in the no. of spikes $/ \mathrm{m}^{2}$ and grain weight $/$ spike and its main components (number of grains/spike and 1000 grain weight) as previously discussed in Table 6. Similar results were attained by other investigators who found that exposing wheat plants to drought stress by decreasing number of irrigation from 5 to 4 or 3 times caused a reduction in grain and biological yields/ha as reported by Soomro et al. (2016) and Razaq et al. (2016). Moreover, El Hag (2017) found that exposing wheat plants to drought stress at stem elongation, booting and/or flowering stages decreased straw yield/fad compared to full irrigation. Moreover, the data show that grain yielding ability as well as translocation indices (crop and harvest indices) were significantly decreased when the wheat plants were exposed to drought stress especially with omitting two irrigation at heading and ripening stages $\left(\mathrm{I}_{3}\right)$. The reduction in such traits 
correlated with exposing wheat plants to drought stress $\left(\mathrm{I}_{3}\right)$ may be due to that the depression rate in grain yield (16.8 \%) was more pronounced than that in straw yield (13.2\%) and biological yield (14.6\%) compared to full irrigation regime $\left(\mathrm{I}_{1}\right)$, as an average of the two seasons. On the other hand, non- significant differences were detected between the application of five irrigation (full irrigation, $I_{1}$ ) and four irrigations (skipping one irrigation at heading date, $I_{2}$ ) for these traits in both seasons. This means that the application of four irrigation produced the same significant values of such traits obtained by the application of five irrigations. In this respect, Akram (2011) and Awad et al. (2015) found insignificant differences among irrigation treatments for harvest index.

The data in Table 7 indicated that Sakha 95 and Gemmeiza $12 \mathrm{cvs}$. significantly surpassed the other two cultivars, i.e. Shandaweel 1 and Misr 3 in grain yield/fad in a descending order during the two seasons. However, Gemmeiza $12 \mathrm{cv}$. significantly exceeded the other three varieties in straw and biological yields/fad without any significant differences among them. Sakha $95 \mathrm{cv}$. was superior to the rest cultivars in translocation indices (crop and harvest indices). On the other hand, Shandaweel 1 and Misr 3 cultivars had the maximum and minimum values of grain yielding ability (21.65 and $19.97 \mathrm{~kg}$ grains/one day), respectively, as an average of both seasons. The superiority of Shandaweel $1 \mathrm{cv}$. in grain yielding ability may be due to its plants were earlier in maturity than those of the other cultivars Table 5. Varietal differences among some wheat cultivar were previously observed by other investigators for grain yield (EL Hag \& Shahein et al., 2017 and Gameh et al., 2017), Straw yield (Awad et al., 2015 and Abd El-Rahman \& El-Saidy, 2016), biological yield (Mekkei \& El Haggan, 2014 and Abdelkhalek et al., 2015) and harvest index (Seleiman et al., 2010 and El Hag, 2017).

The interaction between the tested irrigation regimes and wheat cultivars was found to be significant for grain yield/fad in both seasons, while non - significant differences were recorded between the two factors for the rested characters in the first and/second season one as shown in Table 7. The data illustrated in Fig. 3 showed that grain yield/fad for each wheat cultivar was decreased by exposing the plants to drought stress conditions. The reduction of grain yield/ fad was more pronounced when the plants was exposed to severe drought stress at heading and ripening stages ( $\mathrm{I}_{3}$ regime) compared to full irrigation ( $\mathrm{I}_{1}$ regime). This reduction amounted to 14.4 and $11.7 \%$ (for Misr 3), 16.7 and $12.6 \%$ (for Shandaweel 1), 21.0 and $16.0 \%$ (for Gemmeiza 12) and 21.6 and $19.80 \%$ (for Sakha 95) in the first and second seasons, respectively. From these results, it can be suggested that grain yield/ fad for Misr 3 and Shandaweel $1 \mathrm{cv}$. were less affected by drought stress conditions compared to the other tested wheat cultivars (Gemmeiza 12 and Sakha 95). Previous studies found significant interaction effect between irrigation regimes and wheat cultivars for grain yield/fad as reported by Awad et al. (2015), Milad et al. (2016), El Hag (2017) and Gameh et al. (2017).

\section{Drought susceptibility index (DSI)}

The results of drought susceptibility index (DSI) for grain yield/fad are presented in Table 8. The mean values of the two seasons indicated that cultivars Misr 3 and Shandaweel 1 had DSI values less than one $(>1)$ either at moderate drought stress, i.e. holding one irrigation at heading stage, $I_{2}(0.716$ and 0.546$)$ or at severe drought stress, i.e. omitting two irrigation at heading and ripening stages, $\mathrm{I}_{3}(0.775$ and 0.888$)$. This mean that such two cultivars were relatively drought tolerant.

On the other hand, the other two cultivars namely Gemmeiza 12 and Sakha 95 had DSI values more than one $(<1)$ either at $I_{2}$ regime (1.255 and 1.424) or at $I_{3}$ regime (1.103 and 1.208) indicating that those varieties were relatively drought susceptibility. From these results, it can be concluded that the cultivars having low DSI values (less than one) can be considered to be drought tolerant because they exhibited smaller yield reductions under drought stress compared to non-drought stress condition (full irrigation) as previously discussed in Fig. 3. Similar conclusion were obtained by Fischer \& Maurer (1978), Kilic \& Yagbasanlar (2010) and Awad et al. (2015) who reported that the genotypes with high DSI values $(<1)$ are sensitive to drought stress, but with low DSI values $(>1)$ are resistant to drought stress. In this respect, Abdelghany et al. (2016), Deef et al. (2016) and Noreldin \& Mahmoud (2017) reported that Shandaweel $1 \mathrm{cv}$. had the lowest values of DSI (less than 1) indicating that such cultivar was considered as stress tolerant variety compared to other different wheat varieties. 


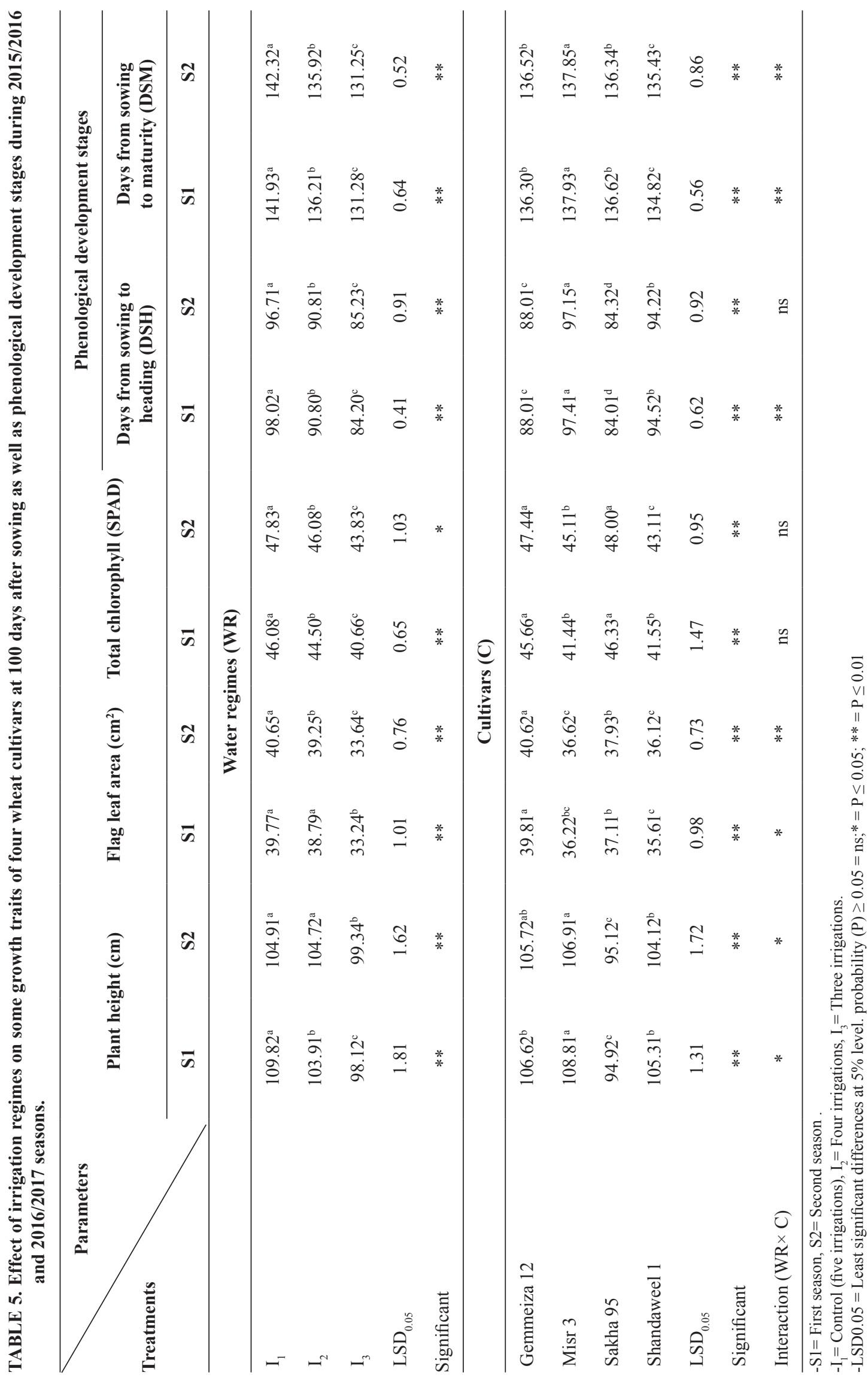

Egypt. J. Agron. 40, No.3 (2018) 


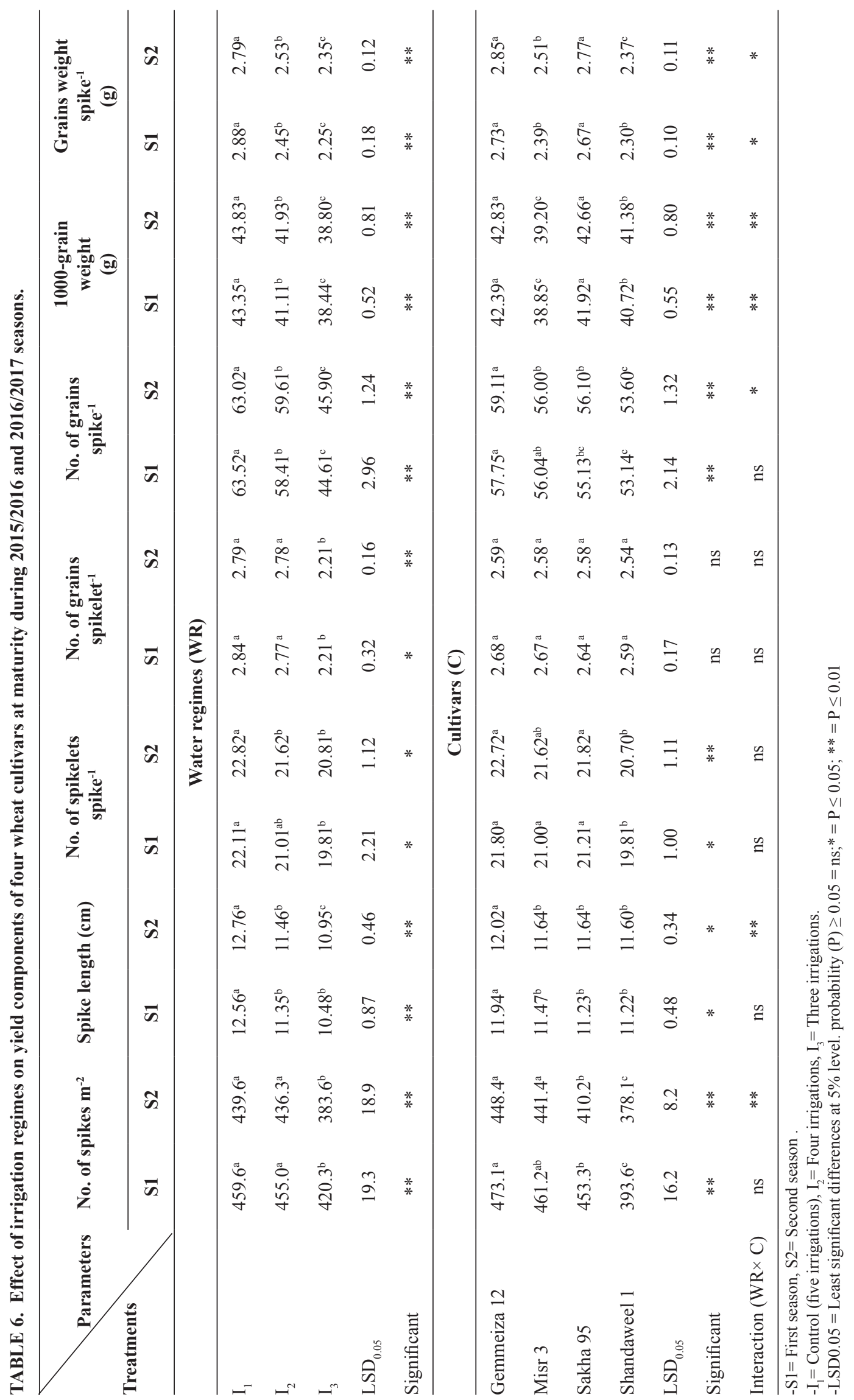

Egypt. J. Agron. 40, No.3 (2018) 


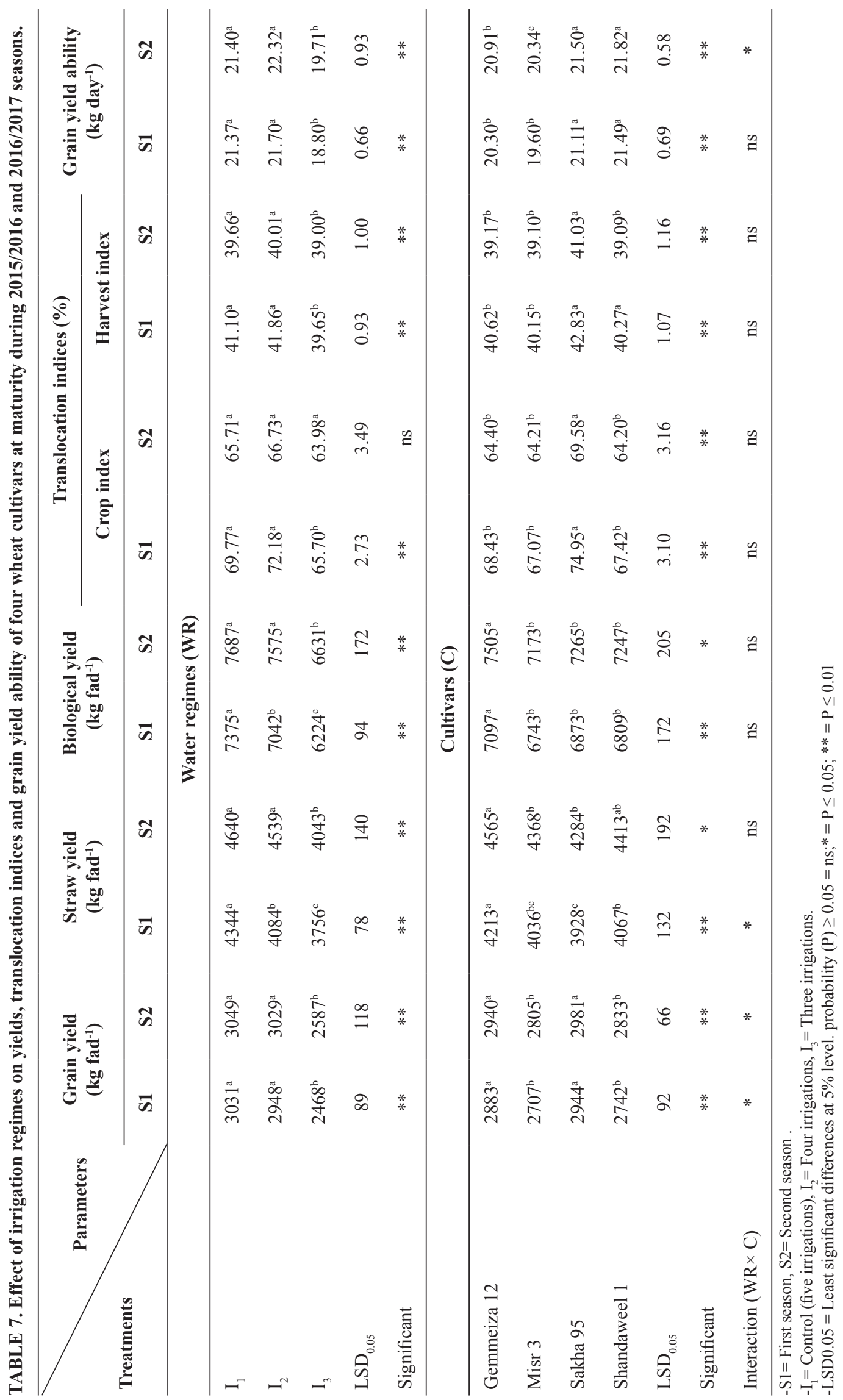

Egypt. J. Agron. 40, No.3 (2018) 


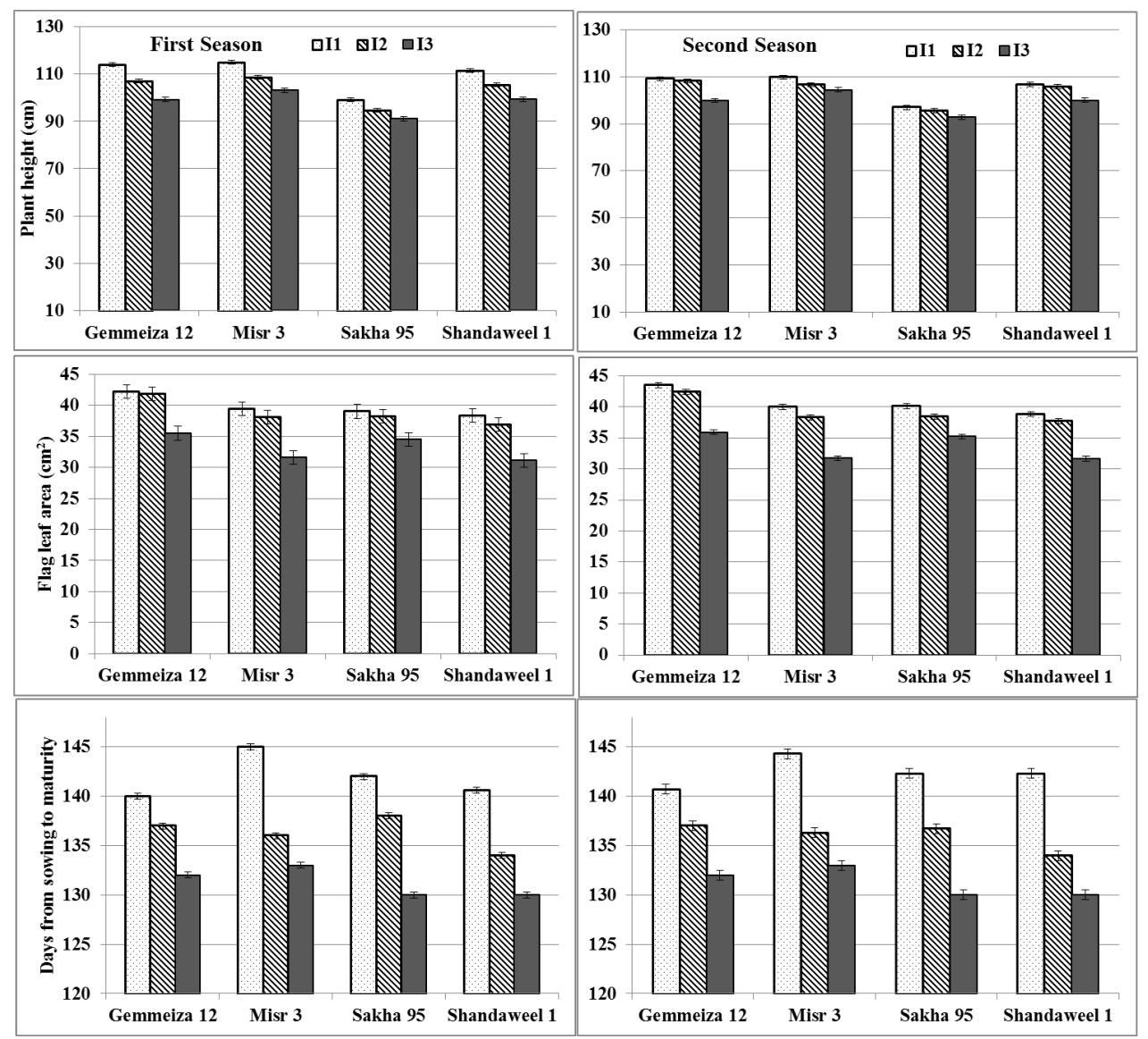

Fig. 1. The interaction effects of water regimes and wheat cultivars on plant height, flag leaf area and days from sowing to maturity (DSM) during 2015/2016 and 2016/2017 seasons $\left(I_{1}=\right.$ Control (five irrigations), $I_{2}=$ Four irrigations and $I_{3}=$ Three irrigations).

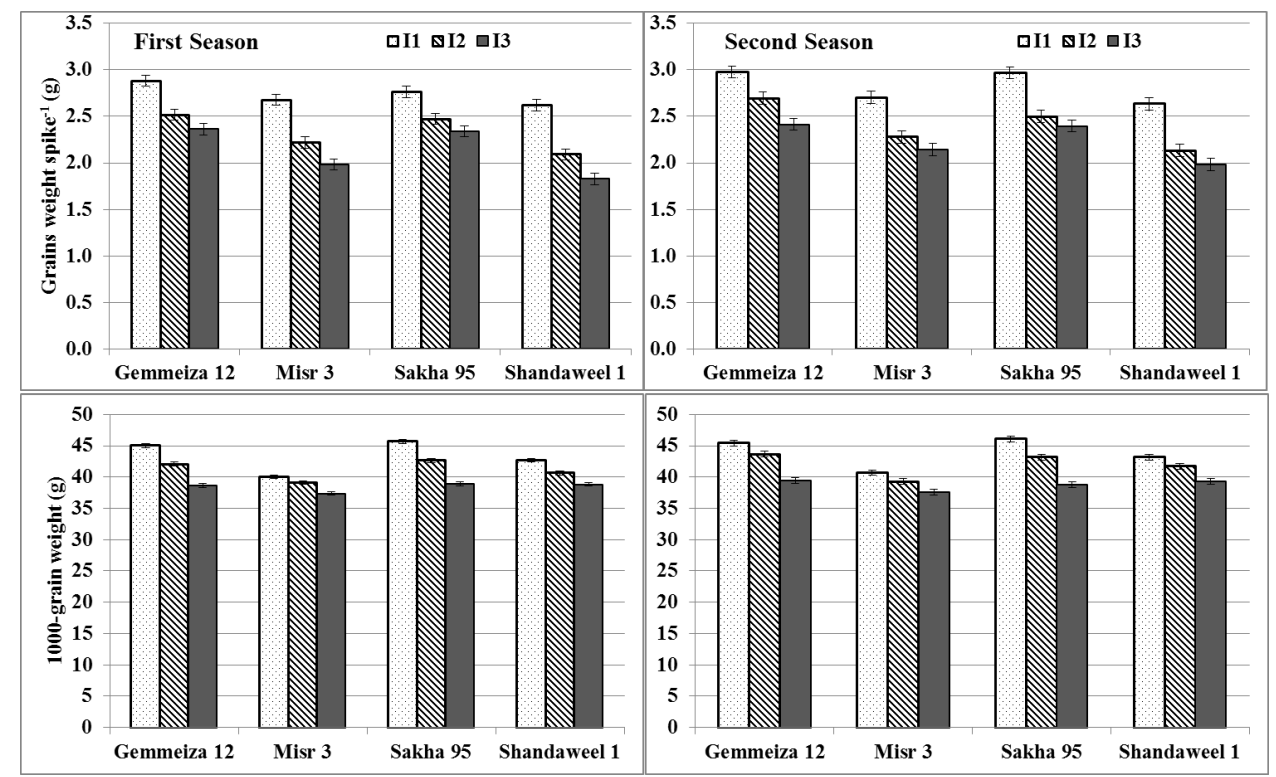

Fig. 2. The interaction effects of water regimes and cultivars on grain weight per spike and 1000-grain weight during 2015/2016 and 2016/2017 seasons ( $I_{1}=$ Control five irrigations, $I_{2}=$ Four irrigations and $I_{3}=$ Three irrigations). 


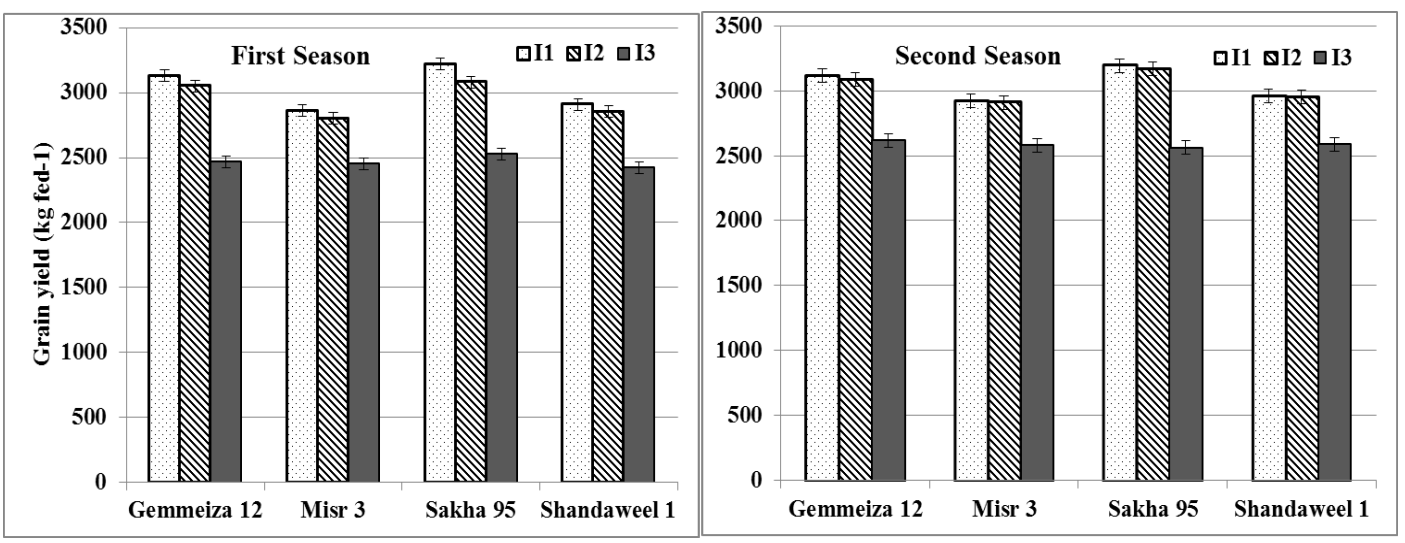

Fig. 3. The interaction effects of water regimes and cultivars on grain yield/fad during 2015/2016 and 2016/2017 seasons $\left(I_{1}=\right.$ Control five irrigations, $I_{2}=$ Four irrigations and $I_{3}=$ Three irrigations).

TABLE 8. Drought susceptibility index (DSI) of wheat cultivars under irrigation regimes during 2015/2016 and 2016/2017 seasons and their means.

\begin{tabular}{lccccc}
\hline $\begin{array}{l}\text { Water } \\
\text { regimes }\end{array}$ & Cultivars & Season 1 & Season 2 & Mean & Susceptibility degree \\
\hline \multirow{4}{*}{$\mathrm{I}_{2}$} & Gemmeiza 12 & 0.888 & 1.622 & 1.255 & Susceptible \\
& Misr 3 & 0.751 & 0.681 & 0.716 & Tolerant \\
& Sakha 95 & 1.587 & 1.262 & 1.424 & Susceptible \\
& Shandaweel 1 & 0.714 & 0.378 & 0.546 & Tolerant \\
$\mathrm{I}_{3}$ & Gemmeiza 12 & 1.172 & 1.034 & 1.103 & Susceptible \\
& Misr 3 & 0.772 & 0.779 & 0.775 & Tolerant \\
& Sakha 95 & 1.106 & 1.310 & 1.208 & Susceptible \\
\hline
\end{tabular}

$-\mathrm{I}_{2}=$ Drought stress at heading (four irrigations), $\mathrm{I}_{3}=$ Drought stress at heading and ripening (three irrigations).

-Susceptibility degree: $<1=$ Tolerant and $>1=$ Susceptible

\section{Grain quality}

Table 9 showed that decreasing number of irrigation from 5 to 3 times significantly increased the total crude protein, but significantly decreased the total carbohydrate percentages in wheat grains in both growing seasons. Wheat grains had the highest values of total crude protein percentage $(14.51 \%)$, but had the lowest values of total carbohydrate percentage ( $68.51 \%$ ) as an average of both seasons when the plants were exposed to drought stress at heading and ripening stages (watered 3 irrigations ). The increment in total crude protein content under skipping irrigation treatments may be due to the reduction in carbohydrate content in the grains owing to the depression of photosynthetic metabolites translocated to grains and consequently dry matter accumulated in them. In this respect, other investigators found that protein $\%$ in grains was increased when the wheat plants were exposed to drought stress at grain filling stage (Mirzaei et al., 2011) or heading stage (Awad et al., 2015). However. Abdelraouf et al. (2013) and El-
Metwally et al. (2015) found that carbohydrate \% was decreased when the plants were irrigated by $50 \%$ or $75 \%$ of water requirements. Moreover, the data in Table 9 indicate that the values of protein and carbohydrate yields/fad were significantly decreased by omitting an irrigation at each of heading and ripening stages (3 irrigations, $\mathrm{I}_{3}$ regime) compared to full irrigation (application of 5 irrigations, $\mathrm{I}_{1}$ regime). However, the differences between four irrigation treatment $\left(\mathrm{I}_{2}\right.$ regime) and five irrigation treatment ( $\mathrm{I}_{1}$ regime) for such traits were not significant at $5 \%$ in both seasons. The depression in the protein and carbohydrate yields/ fad accured herein by skipping two irrigations $\left(\mathrm{I}_{3}\right.$ regime) may be due to the reduction in grain yield/ fad as previously discussed in Table 7.

Results in Table 9 showed that Gemmeiza 12 and Sakha 95 cultivars were superior in protein percentage and yield/fad without significant differences between them. However, the lowest significant values of these traits were recorded 
by Shandaweel 1 and Misr 3. The superiority of Gemmeiza 12 and Sakha 95 cultivars in protein yield/fad may be mainly due to the increase in both of their protein $\%$ and grain yield/fad as shown previously in Table 7. With regard to percentage and yield of carbohydrate, the highest significant values were obtained by Sakha 95 cultivar, while Misr 3 and Shandaweel 1 had the lowest significant ones in both seasons. The superiority of Sakha 95 cultivar in the percentage and yield/ fad of carbohydrate may be due to the increase in its total chlorophyll content (Table 5), 1000 grain weight (Table 6) and grain yield/fad as well as crop index (Table 7). Variations among different wheat cultivar was previously reported by Awad et al. (2015), Abd El-Rahman \& El-Saidy (2016) and EL Hag \& Shahein (2017) for protein \% and by Seleiman et al. (2010) for carbohydrate \%.

With regard to the interaction between irrigation regimes and wheat cultivar, mean values of all studied of grain quality (protein and carbohydrate content) varied insignificantly in the first and/or second seasons as shown in Table 9. This means that the two tested factors independently affected wheat grains quality either as percentage or per fad.

\section{Correlation}

The data of simple correlation coefficient among most studied traits of growth, yield and yield components and quality (overall the tested irrigation regimes and wheat cultivars), as an average of the two growing seasons, are presented in Table 10. The data showed that correlation coefficients were found to be positive and high significant $(\mathrm{P} \leq 0.01)$ among all possible combinations of the following characters, i.e. flag leaf area, total chlorophyll, days from sowing to maturity, number of spikes $/ \mathrm{m}^{2}$, number of grains/ spike, 1000 grain weight, grain weight/spike, grain, straw and biological yields/fad, grain yielding ability and carbohydrate $\%$. Moreover, plant height was positively and significantly correlated with each of flag leaf area, days from sowing to maturity, number of grains/spike and grain weight/spike as well as straw and biological yields/fad. Reversely, total protein $\%$ had significant and negative correlation coefficients with each of plant height, days from sowing to maturity, number of grains/ spike, 1000 grain weight and grain weight/spike as well as grain, straw and biological yields/fad. On the other hand, the correlation coefficients were found to be non-significant mostly between plant height or protein $\%$ with total chlorophyll, number of spikes $/ \mathrm{m}^{2}$, harvest index, grain yielding ability and carbohydrate \%. From the abovementioned results, it can be noted that the highest significant and positive correlation coefficients $(\mathrm{r})$ were attained from grain yield/fad with each of grain yielding ability $\left(\mathrm{r}=0.93^{* *}\right)$, biological yield/fad $(\mathrm{r}$ $\left.=0.92^{* *}\right)$, number of grains/spike $\left(\mathrm{r}=0.86^{* *}\right), 1000$ grain weight $\left(\mathrm{r}=0.85^{* *}\right)$, flag leaf area $\left(\mathrm{r}=0.81^{* *}\right)$, total chlorophyll $\left(\mathrm{r}=0.79^{* *}\right)$, days from sowing to maturity $\left(\mathrm{r}=0.74^{* *}\right)$, harvest index $\left(\mathrm{r}=0.71^{* *}\right)$, grain weight/spike and straw yield/fad $\left(\mathrm{r}=0.70^{* *}\right)$, carbohydrate $\%\left(r=0.65^{* *}\right)$ and number of spikes/ $\mathrm{m}^{2}\left(\mathrm{r}=0.52^{* *}\right)$.

TABLE 9. Effect of irrigations regimes on total crude protein and carbohydrate contents in grains of four wheat cultivars at maturity during 2015/2016 and 2016/2017 seasons.

\begin{tabular}{|c|c|c|c|c|c|c|c|c|}
\hline \multirow{3}{*}{ Treatments } & \multicolumn{4}{|c|}{ Protein } & \multicolumn{4}{|c|}{ Carbohydrate } \\
\hline & \multicolumn{2}{|c|}{$\%$} & \multicolumn{2}{|c|}{ Yield $\left(\mathrm{kg} \mathrm{fad}^{-1}\right)$} & \multicolumn{2}{|c|}{$\%$} & \multicolumn{2}{|c|}{ Yield $\left(\mathrm{kg} \mathrm{fad}^{-1}\right)$} \\
\hline & S1 & S2 & S1 & S2 & S1 & S2 & S1 & S2 \\
\hline $\mathrm{I}_{1}$ & $13.55^{\mathrm{c}}$ & $13.11^{\mathrm{c}}$ & $411.5^{\mathrm{a}}$ & $400.0^{\mathrm{a}}$ & $70.00^{\mathrm{a}}$ & $70.57^{\mathrm{a}}$ & $2121^{\mathrm{a}}$ & $2152^{\mathrm{a}}$ \\
\hline $\mathrm{I}_{2}$ & $14.11^{\mathrm{b}}$ & $14.00^{\mathrm{b}}$ & $416.0^{\mathrm{a}}$ & $424.1^{\mathrm{a}}$ & $69.00^{\mathrm{b}}$ & $69.64^{b}$ & $2034^{\mathrm{a}}$ & $2110^{\mathrm{a}}$ \\
\hline $\mathrm{I}_{3}^{2}$ & $14.53^{\mathrm{a}}$ & $14.50^{\mathrm{a}}$ & $358.7^{\mathrm{b}}$ & $375.2^{\mathrm{b}}$ & $68.39^{c}$ & $68.63^{c}$ & $1688^{b}$ & $1775^{\mathrm{b}}$ \\
\hline Significant & $* *$ & $* *$ & $* *$ & $* *$ & $* *$ & $* *$ & $* *$ & $* *$ \\
\hline \multicolumn{9}{|c|}{ Cultivars (C) } \\
\hline Gemmeiza 12 & $14.38^{\mathrm{a}}$ & $14.35^{\mathrm{a}}$ & $407.4^{\mathrm{a}}$ & $421.9^{a}$ & $69.50^{\mathrm{b}}$ & $69.65^{\mathrm{b}}$ & $2004^{b}$ & $2048^{b}$ \\
\hline Misr 3 & $13.93^{\mathrm{b}}$ & $13.61^{\mathrm{b}}$ & $377.0^{\mathrm{b}}$ & $381.7^{\mathrm{b}}$ & $67.76^{\mathrm{c}}$ & $68.22^{\mathrm{c}}$ & $1834^{\mathrm{c}}$ & $1914^{\mathrm{c}}$ \\
\hline Sakha 95 & $14.20^{\mathrm{a}}$ & $14.27^{\mathrm{a}}$ & $418.0^{\mathrm{a}}$ & $425.4^{\mathrm{a}}$ & $72.02^{\mathrm{a}}$ & $72.31^{\mathrm{a}}$ & $2120^{\mathrm{a}}$ & $2156^{\mathrm{a}}$ \\
\hline Interaction $(\mathrm{WR} \times \mathrm{C})$ & ns & $* *$ & ns & $* *$ & ns & $* *$ & ns & $*$ \\
\hline
\end{tabular}

-S1= First season, $\mathrm{S} 2=$ Second season

$-\mathrm{I}_{1}=$ Control (five irrigations), $\mathrm{I}_{2}=$ Four irrigations, $\mathrm{I}_{3}=$ Three irrigations.

-LSD0.05 = Least significant differences at 5\% level. probability $(\mathrm{P}) \geq 0.05=\mathrm{ns} ;{ }^{*}=\mathrm{P} \leq 0.05 ; * *=\mathrm{P} \leq 0.01$ 


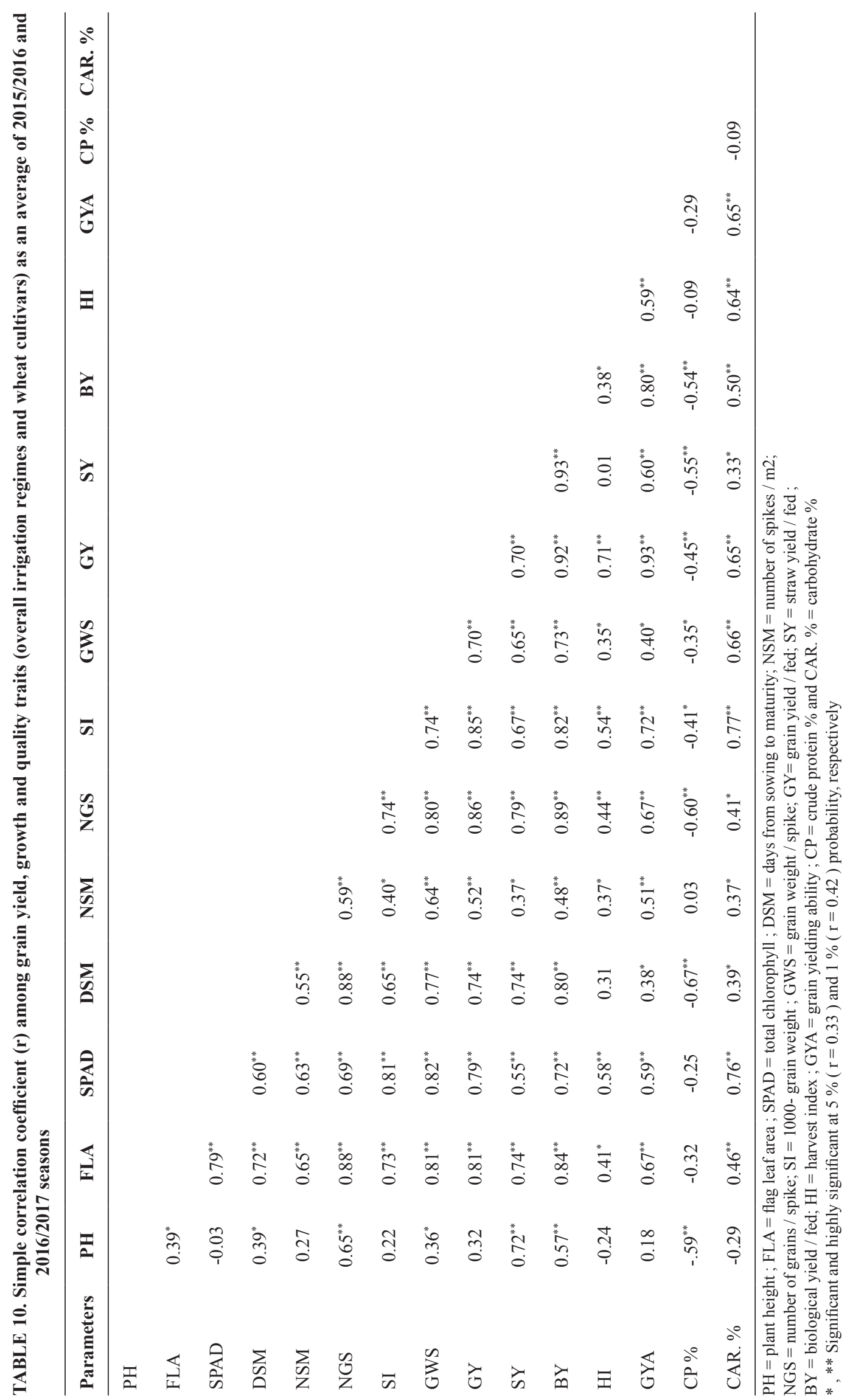

Egypt. J. Agron. 40, No.3 (2018) 
This means that such characters are the most important effective components (in a descending order) for improving grain wheat productivity under over all tested cultivar and irrigation treatments in this study. In this concern, many researchers found positive and significant correlation between grain yield and each of plant height, biological yield, harvest index and 1000 grain weight (Shamsi et al., 2011 and Moghaddam et al., 2012) and days from sowing to maturity, number of spikes $/ \mathrm{m}^{2}$, number of grains/spike and total chlorophyll (Al-Ghzawi et al., 2018). However, negative and significant correlations were obtained between grain yield/ fad and protein \% in grains as reported by Kilic \& Yagabsanlar (2010) and Abd El-Kareem \& ElSaidy (2011).

\section{Conclusion}

From the abovementioned results, it can be noticed that exposing wheat plants to drought stress by skipping two irrigations at heading and ripening stages $\left(\mathrm{I}_{3}\right.$ regime) caused high significant reduction in most traits of growth, yield and yield components and grain quality. However, skipping one irrigation at ripening stage ( $\mathrm{I}_{2}$ regime) caused insignificant reduction in grain, straw and biological yields and most related traits compared to full irrigation (control, $\mathrm{I}_{1}$ regime). Moreover, Misr 3 and Shandaweel 1 cultivars were most tolerant for drought stress where they exhibited lower yield reduction with exposing to drought stress.

Finally, it can be concluded that the application of four irrigations to wheat plants at tillering, stem elongation, booting and heading stages with skipping one irrigation only at ripening stage especially with Misr 3 and Shandaweel 1 cultivars are most profitable to save water consumption without significant reduction in wheat productivity under this experiment conditions.

\section{$\underline{\text { References }}$}

Abd El-Rahman, Magda E. and El-Saidy, Aml E. A. (2016) Response of yield and grain quality of some bread wheat (Triticum aestivum L.) genotypes to different sowing dates. J. Plant Production, Mansoura Univ. 7(10), 1043-1051.

Abdelghany, A.M., Abouzied, Hanaa M. and Badran, M.S. (2016) Evaluation of some Egyptian wheat cultivars under water stress condition in the North
Western Coast of Egypt. J. Agric. \& Env. Sci. Damanhour. Univ., Egypt, 15(1), 63-84.

Abdelkhalek, A.A., Darwesh, R.Kh. and El-Mansoury, Mona A.M. (2015) Response of some wheat varieties to irrigation and nitrogen fertilization using ammonia gas in North Nile Delta region. Annals of Agricultural Science, 60(2), 245-256.

Abdelraouf, R.E., El Habbasha, S.F., Taha, M.H. and Refaie, K.M. (2013) Effect of irrigation water requirements and fertigation levels on growth, yield and water use efficiency in wheat. MiddleEast Journal of Scientific Research, 16(4), 441-450.

Akram, M. (2011) Growth and yield components of wheat under water Stress of different growth stages. Bangladesh J. Agril. Res. 36(3), 455-468.

Akter, S., Sarker, U.K., Hasan, A.K., Uddin, M.R., Hoque, M.M.I. and Mahapatra, C.K. (2018) Effects of mulching on growth and yield components of selected varieties of wheat (Triticum aestivum L.) under field condition. Arch. Agr. Environ. Sci. 3(1), 25-35.

Al-Ghzawi, A. A, Khalaf, Y.B., Al-Ajlouni, Z.I., AL-Quraan, Nisreen. A, Musallam, I. and Hani, N.B. (2018) The effect of supplemental irrigation on canopy temperature depression, chlorophyll content, and water use efficiency in three wheat (Triticum aestivum L. and T. durum desf.) varieties grown in dry regions of Jordan. Agriculture, 8(67), $1-23$.

Awad, A., Abdel-Mottaleb, H.M., Hammada, M.S., Kotb, M.A.A. and Abass M.G. (2015) Effect of drought stress and nitrogen fertilizer on yield and its components of two wheat cultivars (Triticum aestivum L.). Journal of Plant Production Sciences; Suez Canal University, 4, 13-20.

Beltrano, J. and Marta, G. R. (2008) Improved tolerance of wheat plants (Triticum aestivum L.) to drought stress and rewatering by the arbuscular mycorrhizal fungus Glomus claroideum: Effect on growth and cell membrane stability. Braz. J. Plant Physiol. 20(1), 29-37.

Braun, H-J., Atlin, G. and Payne, T. (2010) Multilocation testing as a tool to identify plant response to global climate change. In: "Climate Change and Crop Production", M.P. Reynolds (Ed.), pp 115-138. CABI International. 
Chapman, H.D. and Pratt, P.F. (1978) "Methods of Analysis for Soils, Plants and Waters". Univ. California Div. Agric. Sci. Priced Publication, Oakland.

Deef, Hanan E., Afiah, S.A. and Al-Shahat, Alaa A. (2016) Physiological studies and tolerance indices of six bread wheat genotypes under Siwa Oasis and Ashmon habitats. Egypt. J. Bot. 56(1), 283-302.

Dubois, M., Gilles, K.A., Hamilton, J.K., Rebers, P.A. and Smith, F. (1956) Colorimetric method for determination of sugars and related substances. Anal. Chem. 28(3), 350-356.

El Hag, Dalia A.A. (2017) Effect of irrigations number on yield and yield components of some bread wheat cultivars in north Nile delta of Egypt. Egypt. J. Agron. 39(2), 137-148.

EL Hag, Dalia A.A. and Shahein, Alaa M.E.A. (2017) Effect of different nitrogen rates on productivity and quality traits of wheat cultivars. Egypt. J. Agro. 39(3), 321-335.

El-Metwally, I.M., Abdelraouf, R.E., Ahmed, M.A., Mounzer, O., Alarcón, J.J. and Abdelhamid, M.T. (2015) Response of wheat (Triticum aestivum L.) crop and broad-leaved weeds to different water requirements and weed management in sandy soils. Agriculture (Pol’nohospodárstvo), 61(1), 22-32.

FAOSTAT (2014) http://faostat.fao.org, FAO, Rome, Italy.

FAOSTAT (2015) Wheat Sector Review-Egypt. Report number 21, Rome, Italy. Available at: http://faostat. fao.org (http://www.fao.org/3/a-i4898e.pdf.

Fischer, R. A. and Maurer, R. (1978) Drought resistance in spring wheat cultivars. I- grain yield responses. Aust. J. Agric. Res. 29, 897-912.

Gameh, M.A., Ahmed, E.M., Mohamed, K.A. and Ahmed, M.A.M. (2017) Effect of different dates and irrigation regimes on growth, yield and consumptive use of some wheat varieties under Sohag Governorate conditions. Assiut J. Agric. Sci. 48(1-1), 374-393.

Ibrahim, M.E., Abdel-Aal, S.M., Seleiman, M.F.M., Khazaei, H. and Monneveux, P. (2010) Effect of different water regimes on agronomical traits and irrigation efficiency in bread wheat (Triticum aestivum L.) grown in the Nile Delta. Wheat Inf. Serv. 109, 5-9.

IPCC (2013) The Physical Science Basis. Contribution of Working Group I to the Fifth Assessment Report of the Intergovernmental Panel on Climate Change. Cambridge University Press, Cambridge, UK.

Jackson, M.L. (1973) "Soil Chemical Analysis", 498p. Prentice Hall of India Pvt. Ltd., New Delhi.

Kilic, H. and Yağbasanlar, T. (2010) The effect of drought stress on grain yield, yield components and some quality traits of durum wheat (Triticum turgidum ssp. durum) cultivars. Not. Bot. Hort. Agrobot. Cluj. 38(1), 164-170.

Loggini, B., Scartazza, A., Brugnoli, E. and NavariIzzo, F. (1999) Antioxidative defense system, pigment composition, and photosynthetic efficiency in two wheat cultivars subjected to drought. Plant Physiol. 1091-1099.

Lucas, H. (2013) Wheat Initiative: An International Vision for Wheat Improvement. Available online: www.wheatinitiative.org.

Mekkei, M.E.R. and El Haggan, Eman A.M.A. (2014) Effect of different irrigation regimes on grain yield and quality of some Egyptian bread wheat cultivars. JAAS Journal, 2(9), 275-282.

Milad, Sanaa I.M., Nawar, A.I., Shaalan, A.M., Eldakak, M. and Rohila, J.S. (2016) Response of different wheat genotypes to drought and heat stresses during grain filling stage. Egypt. J. Agron. 38(3), 369-387.

Mirzaei, A, Naseri, R. and Soleimani, R. (2011) Response of different growth stages of wheat to moisture tension in a semiarid land. World Applied Sciences Journal, 12(1), 83-89.

Moghaddam, H.A., Galavi, M., Soluki, M., Siahsar, B.A., Mousavi Nik, S.M. and Heidari, M. (2012) Effects of deficit irrigation on yield, yield components and some morphological traits of wheat cultivars under field conditions. Intl. J. Agric: Res. Rev. 2(6), 825-833.

Noreldin, T. and Mahmoud, M.SH.M. (2017) Evaluation of some wheat genotypes under water stress conditions in Upper Egypt. J.Soil Sci. Agric. Eng., Mansoura Univ. 8(6), 257-265. 
Paknejad, F., Nasri, M., Moghadam, H.R.T., Zahedi, H. and Alahmadi, M.J. (2007) Effect of drought stress on chlorophyll fluorescence parameters, chlorophyll content and grain yield of cultivars. Journal of Biological Sciences, 7(6), 841-847.

Rashid, H.K., Khan, M.Q. and Abasi, M.K.. (2003) Effect of water stress on the performance of wheat grown under controlled conditions at Rawalakot. Azad Jammu and Kashmir. Sarhad J. Agric. 19, 61-62.

Razaq, A., Khan, M.J., Sarwar, T. and Khan, M.J. (2016) Effect of deficit irrigation, sowing methods and mulching on wheat yield and nitrogen uptake. Pakistan J. Agric. Res. 29(3), 222-228.

Seleiman, M.F., Abdel-Aal, S.M., Ibrahim, M.E. and Monneveux, P. (2010) Variation of yield, milling, technological and rheological characteristics in some Egyptian bread wheat (Triticum aestivum L.) cultivar. Emir. J. Food Agric. 22(2), 84-90.

Seleiman, M.F., Abdel-Aal, S., Ibrahim, M. and Zahran, G. (2011) Productivity, grain and dough quality of bread wheat grown with different water regimes. Journal of Agro Crop Sciences, 2(1), 11-17.

Shamsi, K., Petrosyan, M., Mohammadi, G.N., Haghparast, A., Kobraee, S. and Rasekhi, B. (2011) Differential agronomic responses of bread wheat cultivars to drought stress in the west of Iran. African Journal of Biotechnology, 10(14), 2708-2715.
Soomro, N.A., Soomro, A.F., Samo, H.A. and Depar, M.S. (2016) Growth and yield comparisons of four commercial wheat varieties to irrigation frequencies. Pakistan J. Agric. Res. 29(3), 212-221.

Tecator, A.B. (1991) Determination of kjeldahl nitrogen content with Kjeltec Autosystem I, II, III and IV. Tecator Application Note an 30/81, Hogana, Sweden.

Thomas, H. (1975) The growth response of weather of simulated vegetative swards of single genotype of Lolium perenne. The Journal of Agricultural Science, 84, 333-343.

Varga, B., Vida, G., Varga-Lảszló, E., Bencze, S. and Veisz, O. (2015) Effect of simulating drought in various phenophases on the water use efficiency of winter wheat. J. Agro Crop Sci. 201, 1-9.

Zaki, Nabila M., Hassanein, M.S. and Gamal El-Din, Karima M. (2007) Growth and yield of some wheat cultivars irrigated with saline water in newly cultivated land as affected by bio fertilization. Journal of Applied Sciences Research, 3(10), 1121-1126.

(Received 24/11/2018; accepted 25/12/2018) 


\section{استجابة نمو وانتاجية وجودة بعض اصناف قمح الخبز المصرية لأنظمة ري مختلفة \\ محمود فتحى سليمان و محمد سيد محمود عبد العال

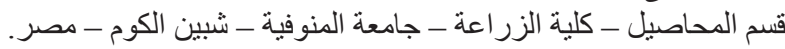

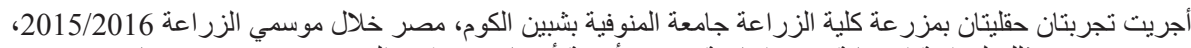

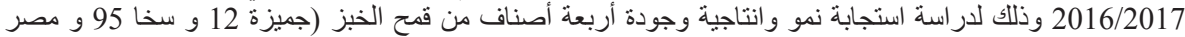

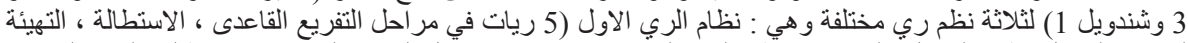

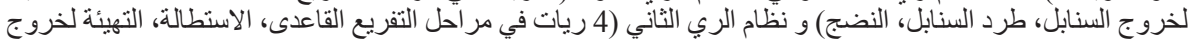

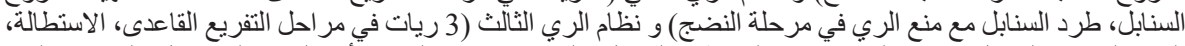

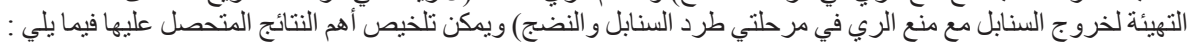

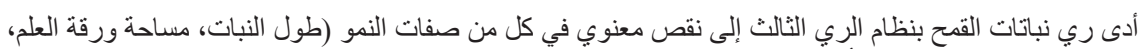

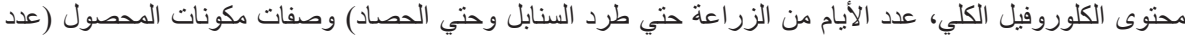

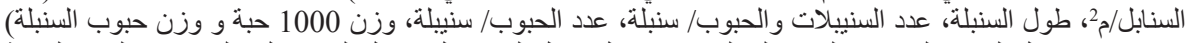
وصفات محصول الفدان (الحبوب و القش و البيولوجي) ودلائل انتقال المحصول (دلائل المحصول ولئل ولئل الحصاد) و القدرة النسبية

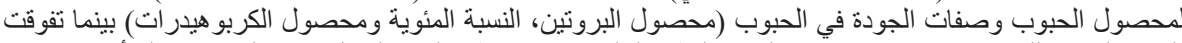

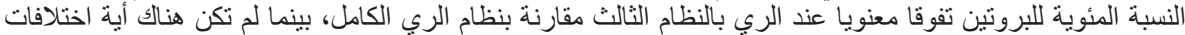

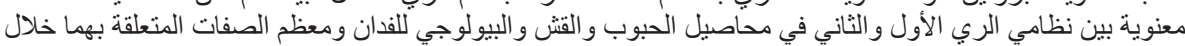
موسمي الزراعة.

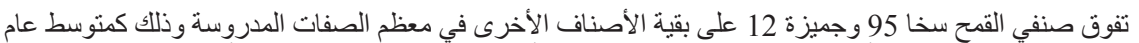

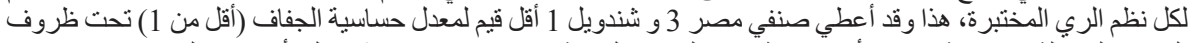

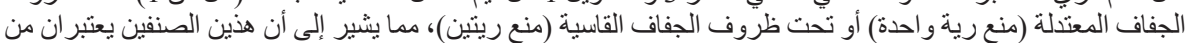
الأصناف التي تتحمل الجفاف مقارنة ببافي الأصناف المختبرة

تثشير نتائج التفاعل إلى أن ري صنفي القمح مصر 3 وشندويل 1 بنظام الري الثاني (4 ريات فقط) كانت أكثر المعاملات

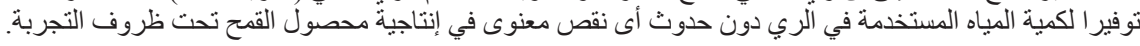

